\title{
A Study on the Factors Affecting the Rural Revitalization in Industrial Industry by Scientific Special Commissioners Based on PLS-SEM
}

\author{
Zhongyan Lin ${ }^{1,2,3,4,5}$, Siyang Zhang ${ }^{2}$, Mingcong Liu ${ }^{2}$, Jiaxi Zhang ${ }^{2}$, Di Chen ${ }^{2}$, Xiaoyuan $\mathrm{Wu}^{5}$, \\ Genping Yu ${ }^{1,3,4}$, Liping Lin ${ }^{1,3,4}$ * \\ ${ }^{I}$ E-Commerce Branch of Fujian Collaborative Innovation Institute, Fuzhou, Fujian, China \\ ${ }^{2}$ Scientific Research Department of Minjiang University, Fuzhou, Fujian, China \\ ${ }^{3}$ Internet Innovation Research Center of Minjiang University, Fuzhou, Fujian, China \\ ${ }^{4}$ Internet Innovation Research Center-The College's Research Base of Humanities and Social Science in \\ Fujian Province, Minjiang University, Fuzhou, Fujian, China \\ ${ }^{5}$ Department of Economic and Management of Minjiang University, Fuzhou, Fujian, China \\ *Correspondence author.
}

\begin{abstract}
Objective: To study the cause and effects of factors affecting the rural revitalization in industrial industry by scientific special commissioners and the intensity of the influence. Method: Using Partial Least Squares Structural Equation Model to make a statistical analysis of the factors that influence the promotion of rural areas by scientific special commissioners in Fuzhou. Result: The model has good reliability, convergent validity and discriminant validity. Conclusions: Policy factors, system factors and the scientific special commissioners' self-factors have a positive impact on the rural revitalization, and scientific special commissioners' self-factors have the greatest impact, followed by system factors and finally policy factors. The conclusion shows that under the background of the effective development of scientific special commissioners' work in Fuzhou guided and organized by governments at all levels, the innovation of policies and systems has achieved certain results in assisting the rural revitalization of scientific special commissioners, especially in the innovation of talent system, which has achieved remarkable results and fully mobilized the intelligence advantages, scientific and technological advantages and creative advantages of scientific special commissioners to serve the rural revitalization.
\end{abstract}

Keywords: scientific special commissioners, rural revitalization, industrial industry, Partial Least Squares Structural Equation Model (PLS-SEM)

\section{Introduction}

On March 22, 2021, the CPC Central Committee and the State Council issued the Opinions on Achieving the Effective Link between Consolidating and Expanding the Achievements of Poverty Alleviation and Rural Revitalization, which pointed out that after winning the battle to eradicate poverty and building a well-off society in an all-round way, we should further consolidate and expand the achievements of poverty alleviation and continue to promote the development of poverty-stricken areas and the overall revitalization of villages.

The system of scientific special commissioners, as an important starting point for comprehensive rural revitalization originated from Nanping City, Fujian Province, with a history of 32 years, is an institutional arrangement derived from grassroots exploration, the needs of the masses, and practical innovation, aimed to guide all kinds of scientific and technological innovative and entrepreneurial personnel and teams and integrate modern production factors such as science and technology, information, capital, management to go deep into rural

ISSN: 0010-8189

(C) CONVERTER 2020 
grassroots to carry out technology entrepreneurship and services, and establish a community of "sharing risks and benefits" with farmers to promote the in-depth development of rural innovation and entrepreneurship.

Since the implementation of the system of scientific special commissioners, individuals, teams and legal persons have provided three-dimensional assistance to farmers and township enterprises, and promoted the new "mass entrepreneurship and innovation" model and imported new development concepts for rural areas while teaching new agricultural technologies. With advanced technology and ideas, individual scientific special commissioners generally advocate the hands-on training demonstration mode of "showing and leading farmers", which not only innovates the rural science and technology system, but also improves the quality of workers. In addition, Fujian province encourages and guides scientific special commissioners to invest in shares with technology and funds, and adopts the interest community model of "sharing risks and benefits" to attract them to serve the countryside in peace for mutual benefit. Meanwhile, the team with universities and research institutes as the main body, as well as the legal persons, build a new platform for innovation and entrepreneurship in schools and villages around their own advantages in scientific research and the characteristics of the industries they support. Up to 2020, Fujian Province has built 102 "Xingchuang Tiandi" at or above the provincial level, providing a broad stage for scientific and technological personnel to take root in the countryside. Moreover, the mode of team and legal person avoids the phenomenon of "scientific research results lying in drawers" in universities and research institutes, and also increases their income and performance, which greatly mobilizes the initiative of relevant units.

In contrast to traditional agricultural technology extension services, science and technology special commissioners need to have a full understanding of the agricultural development in service areas in addition to transmitting their scientific and technological knowledge to farmers. They need to disseminate agricultural technology knowledge and conduct training in accordance with the requirements of future industrial development, participate in agricultural production as project leaders or team technical advisors, build bridges between scientific research laboratories and farmland, and conduct research in the fields.

At present, Fuzhou City has included the innovation and entrepreneurship work of scientific special commissioners into the scope of the "mass entrepreneurship and innovation" work, fully implemented the relevant policies of the state and provinces and cities to promote the transformation of scientific and technological achievements, and encouraged the scientific special commissioners to invest in enterprises with scientific and technological achievements and intellectual property rights to get legal benefits. Scientific special commissioners dispatched by Fuzhou University, Fujian Agriculture and Forestry University, Fujian Normal University and other universities, as well as Fujian Academy of Agricultural Sciences, Fuzhou Institute of Agricultural Sciences wearing different hats served the local development in an all-round way from the aspects of concept guidance, technical guidance, project introduction, capital introduction and system guarantee. In recent years, legal person scientific special commissioners have directly settled in rural areas to guide agricultural production in terms of capital, technology, circulation and equipment, forming a basic model of "company +farmers" and providing targeted technical services for regional characteristic industries.

\section{Data and Methods}

In order to better understand the situation of scientific special commissioners in Fuzhou and help rural revitalization, the project team designed a questionnaire for Promoting Rural Revitalization by Scientific Special Commissioners, including the basic situation of scientific special commissioners and the corresponding scale which mainly consists of 25 core items, including policy factors, system factors and self-factors. The specific contents of the questionnaire are shown in the appendix.

The questionnaires were distributed to local scientific special commissioners via the Internet. Each item was scored based on the likert scale with values from 1 to 5 indicating very non-conformance (very small), relatively non-conformance (small), generally conformance (general), relatively conformance (large) and very conformance

ISSN: 0010-8189

(C) CONVERTER 2020

Www.converter-magazine.info 
(very large). All the items in the scale were positive items, and the items were directly scored based on values from 1 to 5 . See Table 1 for categorical scale.

The Partial Least Squares Structural Equation Modeling (PLS-SEM) was used to analyze how strong and weak relationships among policy factors, system factors, and self-factors that affect the roles and effect of scientific special commissioners in promoting rural revitalization. Policy factors, system factors, self-factors, roles and effects in the scale were set as construct (variables), and the observation indicators were taken as measurement items. PLS approach can be used to achieve the operations of model path, model identification, model estimation and model test, which is achieved by Smart PLS 3.0 software.

Table 1 Constructs and Measurement items of factors affecting rural revitalization by scientific special commissioners

\begin{tabular}{|c|c|c|c|}
\hline Policy factors & System factors & Self-factors & Roles and effects \\
\hline $\begin{array}{l}\text { Policy implementation } \\
\text { (Policy1) }\end{array}$ & $\begin{array}{l}\text { Funding support } \\
\text { (System1) }\end{array}$ & $\begin{array}{l}\text { Enthusiasm of work } \\
\text { affected by income } \\
\quad \text { (Self_factor1) }\end{array}$ & $\begin{array}{l}\text { Effect on the growth of } \\
\text { agricultural products output } \\
\text { of the service objects } \\
\text { (Effect1) }\end{array}$ \\
\hline $\begin{array}{l}\text { Regular training } \\
\text { (Policy2) }\end{array}$ & $\begin{array}{c}\text { Reduction and exemption } \\
\text { of workload in original } \\
\text { unit (System } 2)\end{array}$ & $\begin{array}{l}\text { Understanding on the } \\
\text { policy of scientific } \\
\text { special commissioners } \\
\text { (Self_factor2) }\end{array}$ & $\begin{array}{l}\text { Effect on reducing production } \\
\text { costs for the service objects } \\
\text { (Effect } 2)\end{array}$ \\
\hline $\begin{array}{c}\text { Desirable number of } \\
\text { scientific special } \\
\text { commissioners (Policy3) }\end{array}$ & $\begin{array}{c}\text { Perfect evaluation } \\
\text { mechanism (System3) }\end{array}$ & $\begin{array}{c}\text { Employment level } \\
\text { proportional to work } \\
\text { enthusiasm } \\
\text { (Self_factor3) }\end{array}$ & $\begin{array}{c}\text { Effect on increasing sales } \\
\text { volume of the service objects } \\
(\text { Effect } 3)\end{array}$ \\
\hline \multirow[t]{6}{*}{$\begin{array}{c}\text { The influence of } \\
\text { dispatching methods on } \\
\text { scientific and } \\
\text { technological services } \\
\text { (Policy4) }\end{array}$} & $\begin{array}{l}\text { Appraising opportunities } \\
\text { (System4) }\end{array}$ & $\begin{array}{l}\text { The ability to update } \\
\text { knowledge reserves } \\
\text { (Self_factor4) }\end{array}$ & $\begin{array}{c}\text { Effect on increasing revenue } \\
\text { of the service objects } \\
\text { (Effect } 4)\end{array}$ \\
\hline & $\begin{array}{c}\text { Fit between scientific and } \\
\text { technological work and } \\
\text { own skills (System5) }\end{array}$ & $\begin{array}{l}\text { Communication with } \\
\text { farmers (Self_factor5) }\end{array}$ & $\begin{array}{c}\text { Effect on providing } \\
\text { originality for the service } \\
\text { objects (Effect5) }\end{array}$ \\
\hline & & $\begin{array}{l}\text { Regular training at fixed } \\
\text { places (Self_factor6) }\end{array}$ & $\begin{array}{l}\text { Effect on helping service } \\
\text { objects introduce new } \\
\text { resources (Effect6) }\end{array}$ \\
\hline & & $\begin{array}{l}\text { Building a brand with } \\
\text { local advantages } \\
\text { (Self_factor7) }\end{array}$ & \\
\hline & & $\begin{array}{l}\text { Promoting with the } \\
\text { platform of benefiting } \\
\text { farmers and helping } \\
\text { farmers (Self_factor8) }\end{array}$ & \\
\hline & & Solving major & \\
\hline
\end{tabular}

ISSN: 0010-8189

(C) CONVERTER 2020 




\section{Result}

\subsection{Demographic characteristics of the respondents}

A total of 52 valid questionnaires were collected, all of which were scientific special commissioners, including 39 in Fuzhou, 12 in Xiamen, 1 in Putian. Among these 52 scientific special commissioners, 50 scientific special commissioners are from universities. The demographic characteristics are shown in Table 2, which shows that the distribution of science and technology commissioners is relatively uniform in terms of gender, with age groups ranging from 30 to 50 years old. $96.1 \%$ of them have a master's degree or above. There are 50 people with senior or middle professional titles. They basically do not hold administrative posts and their working years range from 0 to 3 years. They are mainly provincial commissioners.

Table 2 Demographic characteristics of respondents $(\mathrm{N}=52)$

\begin{tabular}{|c|c|c|c|}
\hline Demographic variables & Groups & $\mathrm{N}$ & Percent $(\%)$ \\
\hline \multirow{2}{*}{ Gender } & Male & 28 & 53.8 \\
\hline & Female & 24 & 46.2 \\
\hline \multirow{5}{*}{ Age } & 20-29 year-old & 4 & 7.7 \\
\hline & 30-39 year-old & 24 & 46.2 \\
\hline & 40-49 year-old & 18 & 34.6 \\
\hline & $50-59$ year-old & 6 & 11.5 \\
\hline & Above 60 year-old & 0 & 0.0 \\
\hline \multirow{3}{*}{ Education } & Bachelor & 2 & 3.8 \\
\hline & Master & 19 & 36.5 \\
\hline & Doctor & 31 & 59.6 \\
\hline \multirow{5}{*}{ Working units } & $\begin{array}{l}\text { Organs and institutions (except } \\
\text { universities) }\end{array}$ & 1 & 1.9 \\
\hline & Enterprises & 0 & 0.0 \\
\hline & Universities & 50 & 96.2 \\
\hline & Scientific research institutions & 1 & 1.9 \\
\hline & Others & 0 & 0.0 \\
\hline \multirow{4}{*}{$\begin{array}{l}\text { Years of working as a } \\
\text { scientific special } \\
\text { commissioner }\end{array}$} & Less than 1 year & 16 & 30.8 \\
\hline & $1-3$ year(s) & 34 & 65.4 \\
\hline & $4-5$ years & 1 & 1.9 \\
\hline & Over 5 years & 1 & 1.9 \\
\hline \multirow{4}{*}{$\begin{array}{c}\text { Type of scientific } \\
\text { special commissioner }\end{array}$} & Provincial level & 39 & 75.0 \\
\hline & Prefecture-level & 6 & 11.5 \\
\hline & County and district level & 7 & 13.5 \\
\hline & Others & 0 & 0.0 \\
\hline \multirow{4}{*}{$\begin{array}{l}\text { Professional and } \\
\text { technical titles }\end{array}$} & Senior & 35 & 67.3 \\
\hline & Intermediate & 15 & 28.8 \\
\hline & Junior & 0 & 0.0 \\
\hline & Others & 2 & 3.8 \\
\hline \multirow{2}{*}{$\begin{array}{l}\text { Holding administrative } \\
\text { posts or not }\end{array}$} & Yes & 2 & 3.8 \\
\hline & No & 50 & 96.2 \\
\hline
\end{tabular}

ISSN: 0010-8189

(C) CONVERTER 2020 
In the service fields of the interviewed scientific special commissioners, the percentages of transformation of agricultural science and technology achievements, e-commerce application and planning, planting industry, animal husbandry and aquaculture, culture, science and technology, and health care are all around 13\%, while 48\% are in other professional fields. Besides, $80.8 \%$ of the scientific special commissioners indicated that they had received information support from the government when providing science and technology services, $86.5 \%$ indicated that the government had provided relevant policy guarantees, and $80.8 \%$ indicated that they had some understanding of the government's policies on scientific special commissioners. 82.7\% of the interviewees believed that their work as a scientific special commissioner played a role in the revitalization of the villages, $55.8 \%$ provided science and technology services less than 12 times in that year, and $40.4 \%$ provided two to three times a month on average.

Table 3 Purpose of joining scientific special commissioners and their related views on rural revitalization

\begin{tabular}{|c|c|c|c|c|}
\hline \multirow{2}{*}{ Items } & \multirow{2}{*}{ Options } & \multicolumn{2}{|c|}{ Response sets } & \multirow{2}{*}{$\begin{array}{l}\text { Percentage of } \\
\text { cases }(\%)\end{array}$} \\
\hline & & $\mathrm{N}$ & Percentage $(\%)$ & \\
\hline \multirow{5}{*}{$\begin{array}{l}\text { Purpose of joining } \\
\text { scientific special } \\
\text { commissioners }\end{array}$} & Increasing income & 3 & 4.6 & 5.8 \\
\hline & $\begin{array}{c}\text { Identity as a scientific special } \\
\text { commissioner and professional title } \\
\text { appraisal }\end{array}$ & 8 & 12.3 & 15.4 \\
\hline & $\begin{array}{c}\text { Promoting agricultural and rural } \\
\text { development }\end{array}$ & 29 & 44.6 & 55.8 \\
\hline & $\begin{array}{c}\text { Popularize innovative agricultural } \\
\text { technologies }\end{array}$ & 10 & 15.4 & 19.2 \\
\hline & Others & 15 & 23.1 & 28.8 \\
\hline Total & & 65 & 100.0 & 125.0 \\
\hline \multirow{6}{*}{$\begin{array}{l}\text { Key supports for } \\
\text { rural revitalization }\end{array}$} & Correct guidance of national policies & 43 & 19.8 & 82.7 \\
\hline & $\begin{array}{l}\text { Support from government project } \\
\text { funds }\end{array}$ & 42 & 19.4 & 80.8 \\
\hline & Investment promotion & 24 & 11.1 & 46.2 \\
\hline & $\begin{array}{l}\text { Collective efforts of villagers and } \\
\text { government }\end{array}$ & 43 & 19.8 & 82.7 \\
\hline & The villagers' efforts & 26 & 12.0 & 50.0 \\
\hline & $\begin{array}{l}\text { Assistance from scientific special } \\
\text { commissioners }\end{array}$ & 39 & 18.0 & 75.0 \\
\hline Total & & 217 & 100 & 417.3 \\
\hline \multirow{6}{*}{$\begin{array}{l}\text { Problems existing } \\
\text { in rural } \\
\text { revitalization of } \\
\text { current service } \\
\text { objects }\end{array}$} & $\begin{array}{l}\text { Less investment in poverty alleviation } \\
\text { funds }\end{array}$ & 23 & 18.5 & 44.2 \\
\hline & Low public participation & 37 & 29.8 & 71.2 \\
\hline & $\begin{array}{l}\text { Not obvious increment of industrial } \\
\text { projects }\end{array}$ & 38 & 30.6 & 73.1 \\
\hline & $\begin{array}{l}\text { Insufficient supervision of poverty } \\
\text { alleviation funds }\end{array}$ & 10 & 8.1 & 19.2 \\
\hline & $\begin{array}{c}\text { Poor publicity of poverty alleviation } \\
\text { policies }\end{array}$ & 10 & 8.1 & 19.2 \\
\hline & Others & 6 & 4.8 & 11.5 \\
\hline Total & & 124 & 100 & 238.5 \\
\hline
\end{tabular}

Table 3 shows that promoting the rural development is one of the purposes for which $55.8 \%$ of the respondents joined the scientific special commissioners, with the highest percentage; the correct guidance of national policies and the financial support of government projects are considered by most of the respondents as one of the main factors for rural revitalization; the low public participation and not obvious increment of industrial projects are considered by most of the respondents as one of the problems existing in the rural revitalization of the service

ISSN: 0010-8189

(C) CONVERTER 2020

www.converter-magazine.info 
objects at present, and $44.2 \%$ of the respondents considered that the less investment in poverty alleviation funds is one of the problems existing in the rural revitalization of the service objects at present.

\subsection{PLS-SEM model for factors affecting the rural revitalization by scientific special commissioners}

\subsubsection{Basic theory of PLS-SEM}

Structural Equation Modeling (SEM) is a multivariate statistical method proposed by Swedish statistician Karl G.Joreskog in 1970s, which is used to effectively deal with and test the relationship between measurement model and structural model. The measurement model represents the relationship between variables and indicators, while the structural model represents the relationship between variables. One of its developments is to use indicators of latent variables, which can not be measured directly and accurately or can be observed. And for that variables which cannot be measured directly in social science research can also be included in the scope of empirical research. So structural equation model is widely used in the fields of economy, finance, psychology and other fields.

Partial Least Squares (PLS) structural equation model, a new method proposed by Wood in 1980s. It does not require variables to conform to normal distribution and needs fewer samples. It combines multiple linear regression (MLR) and principal component regression (PCR) and overlaps them (Lin liping et al., 2020 [1]). PLS allows multiple independent latent variables and indicators to be modeled simultaneously to describe the relationship between the measurement model and the structural model (Gefen et al., 2000 [2]). Instead of distinguishing dependent variables from independent variables, PLS distinguishes exogenous variables from endogenous variables. Moreover, PLS can solve the problem of measurement error, explain the variation structure of endogenous latent variables to the greatest extent, and effectively improve the empirical ability of the model.

\subsubsection{Path diagram of structural equation model}

When studying specific problems with structural equation model, it is usually necessary to draw a structural equation path diagram based on the prior information already mastered and the comprehensive consideration of the specific environment, so as to briefly represent the structure of the analyzed problem, the number of latent variables, the number of indicators and the relationship between each variable (He Tao, 2006 [3]).

Since the PLS model with multiple potential variables is generalized based on two potential variables, we first pay attention to the PLS model with two potential variables in this section (see Fig. 1). Exogenous variables are determined by factors outside the model, which are equivalent to independent variables, that is, variable (x) represents exogenous variables. In the same way, endogenous variables are theoretically determined by the factors in the model, which are equivalent to dependent variables, that is, variable (y) represents endogenous variables.

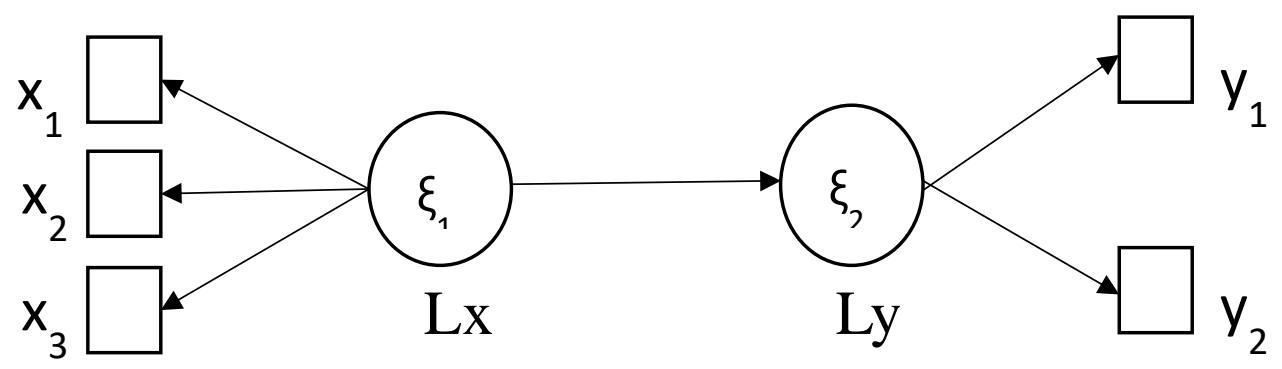

Fig. 1 Path diagram of structural equation model with two latent variables

In fig. $1, \xi_{1}$ and $\xi_{2}$ represent exogenous variables and endogenous variables. It is assumed that $\xi_{1}$ is composed of $X_{1}$, $\mathrm{X}_{2}$ and $\mathrm{X}_{3}$, and $\xi_{2}$ is composed of $\mathrm{Y}_{1}$ and $\mathrm{Y}_{2}$. The relationship between $\xi_{1}$ and $\mathrm{X}_{1}, \mathrm{X}_{2}$ and $\mathrm{X}_{3}$ is called measurement model, and that between $\xi_{1}$ and $\xi_{2}$ is called structural model. Lx and Ly are their PLS estimates respectively.

ISSN: 0010-8189

(C) CONVERTER 2020 
3.2.3 PLS-SEM path diagram of factors affecting the rural revitalization by scientific special commissioners According to the above constructs (see table 1), the path diagram of structural equation model of influencing factors of quality of life is formed (as shown in Fig. 2), and we present the following hypotheses:

$\mathrm{H}_{1}$ : Policy factors have a positive impact on roles and effects;

$\mathrm{H}_{2}$ : System factors have a positive impact on roles and effects;

$\mathrm{H}_{3}$ : Self-factors have a positive impact on roles and effects;

The original hypothesis $\mathrm{H}_{0}$ refers to that the above three domains factors have nothing to do with roles and effects.



Fig. 2 PLS-SEM path diagram of factors affecting the rural revitalization by scientific special commissioners

3.2.4 Reliability and validity evaluation of PLS-SEM model for factors affecting the rural revitalization by scientific special commissioners

The value of Cronbach's Alpha (Cronbach coefficient method) that was proposed by Lee Cronbach in 1951 is used to determine whether the model is reliable or not. Generally, according to the concept of Nunnally(1978), if Cranbach's Alpha value is above 0.6, it is considered to have high credibility (Lin Liping, 2020 [4]). Table 4 shows that Cronbach's Alpha values are all greater than 0.7, indicating that the measurement results is reliable.

Convergent validity used to test the degree to which multiple items that measure the same concept are in agreement. It is evaluated by factor loading, composite reliability (CR), and average variance extracted (AVE), which was suggested by Hair (Hair et al. 2006 [5]). The loading indicates the load of the observation indicator on the common factor of a construct and the size of the loading indicates whether the observation indicator can effectively reflect the construct to be measured. Composite Reliability (CR) represents the degree to which the construct indicators indicate the latent construct composed of more than one observation indicator, that is, the degree to which all measurement indexes share the construct. The higher the CR value, the stronger the intrinsic correlation between observation indexes. Average Variance Extracted (AVE) reflects the overall amount of variance in the indicators occupied by the latent construct, that is, it directly shows how much variation explained by potential variables comes from measurement errors. The higher the AVE value, the greater the variation percentage of observation indicators explained by classified variables, and the smaller the relative measurement errors. Table 4 also shows that the loadings of convergent validity is higher than the recommended value of 0.6(Chin.et.al., 1997 [6]), the composite reliability value is higher than 0.8 , both higher than the recommended value of 0.7(Hair et.al., 2006 [5]), and the average extracted variance value is higher than the recommended value of 0.5 (Hair et.al., 2006 [5]).

Discriminant validity is used to detect the degree to which items differentiate among constructs. Table 5 shows all the square roots of the average variance extracted for the construct is higher than the correlation values in the row, which proved the discriminant validity of the measurement model is good.To sum up, PLS-SEM model for factors affecting the rural revitalization by scientific special commissioners has good reliability, convergent validity and discriminant validity, that is, the evaluation of the model is reliable and effective.

ISSN: 0010-8189

(C) CONVERTER 2020 
Table 4 Reliability and convergent validity of the model

\begin{tabular}{|l|c|c|c|c|c|c|}
\hline $\begin{array}{l}\text { Constru } \\
\text { ct }\end{array}$ & Measurement items & $\begin{array}{c}\text { Cronba } \\
\text { ch's } \\
\text { alpha }\end{array}$ & $\begin{array}{c}\text { Range } \\
\text { of } \\
\text { loading }\end{array}$ & $\begin{array}{c}\text { Composite } \\
\text { Reliability } \\
\text { (CR) }\end{array}$ & $\begin{array}{c}\text { Average } \\
\text { Variance } \\
\text { Extracted } \\
\text { (AVE) }\end{array}$ & $\begin{array}{c}\text { Numbe } \\
\text { r of } \\
\text { items }\end{array}$ \\
\hline $\begin{array}{l}\text { Policy } \\
\text { factors }\end{array}$ & Policy1, Policy2, Policy3, & 0.781 & $\begin{array}{c}0.631-0 \\
.944\end{array}$ & 0.869 & 0.695 & $3(3)$ \\
\hline $\begin{array}{l}\text { System } \\
\text { factors }\end{array}$ & System2, System3, System4, & 0.746 & $\begin{array}{c}0.687-0 \\
.829\end{array}$ & 0.839 & 0.568 & $4(4)$ \\
\hline $\begin{array}{l}\text { Self-fac } \\
\text { tors }\end{array}$ & $\begin{array}{l}\text { Self_factor2, Self_factor5, } \\
\text { Self_factor6, Self_factor7, }\end{array}$ & 0.899 & $\begin{array}{c}0.720-0 \\
.898\end{array}$ & 0.923 & 0.669 & $6(6)$ \\
\hline $\begin{array}{l}\text { Roles } \\
\text { and } \\
\text { effects }\end{array}$ & Effect1, Effect2, Effect3, Effect4, \\
\hline
\end{tabular}

Note: Policy4 (0.389), System1 (0.465), Self_factor1 (0.410), Self_factor3 (0.453) and Self_factor4 (0.556) are deleted due to their lower loadings.

Table 5 Discriminant validity of constructs

\begin{tabular}{|c|c|c|c|c|}
\hline Constructs & Roles and effects & System factors & Policy factors & Self-factors \\
\hline Roles and effects & 0.838 & & & \\
\hline System factors & 0.608 & 0.754 & & \\
\hline Policy factors & 0.610 & 0.674 & 0.834 & \\
\hline Self-factors & 0.794 & 0.719 & 0.727 & 0.818 \\
\hline
\end{tabular}

Note: the diagonal values represent the square root of AVE, while the values of other entries represent the squared correlation.

3.2.5 PLS-SEM model for factors affecting the rural revitalization by scientific special commissioners

The PLS-SEM model (Fig.3) for the factors affecting the rural revitalization by scientific special commissioners can be constructed to analyze the causal relationship and how strong and weak between measurement model and structural model. Fig. 3 shows that the value of $\mathrm{R}^{2}$ for PLS-SEM model is 0.634 , and the closer $\mathrm{R}^{2}$ is to 1 , the more accurate the model is, the more significant the regression effect is, and the more significant the model effect is. This further confirms that the model for factors affecting the rural revitalization by scientific special commissioners can explain $63.4 \%$ of the regression effect, and all three hypotheses are valid. 


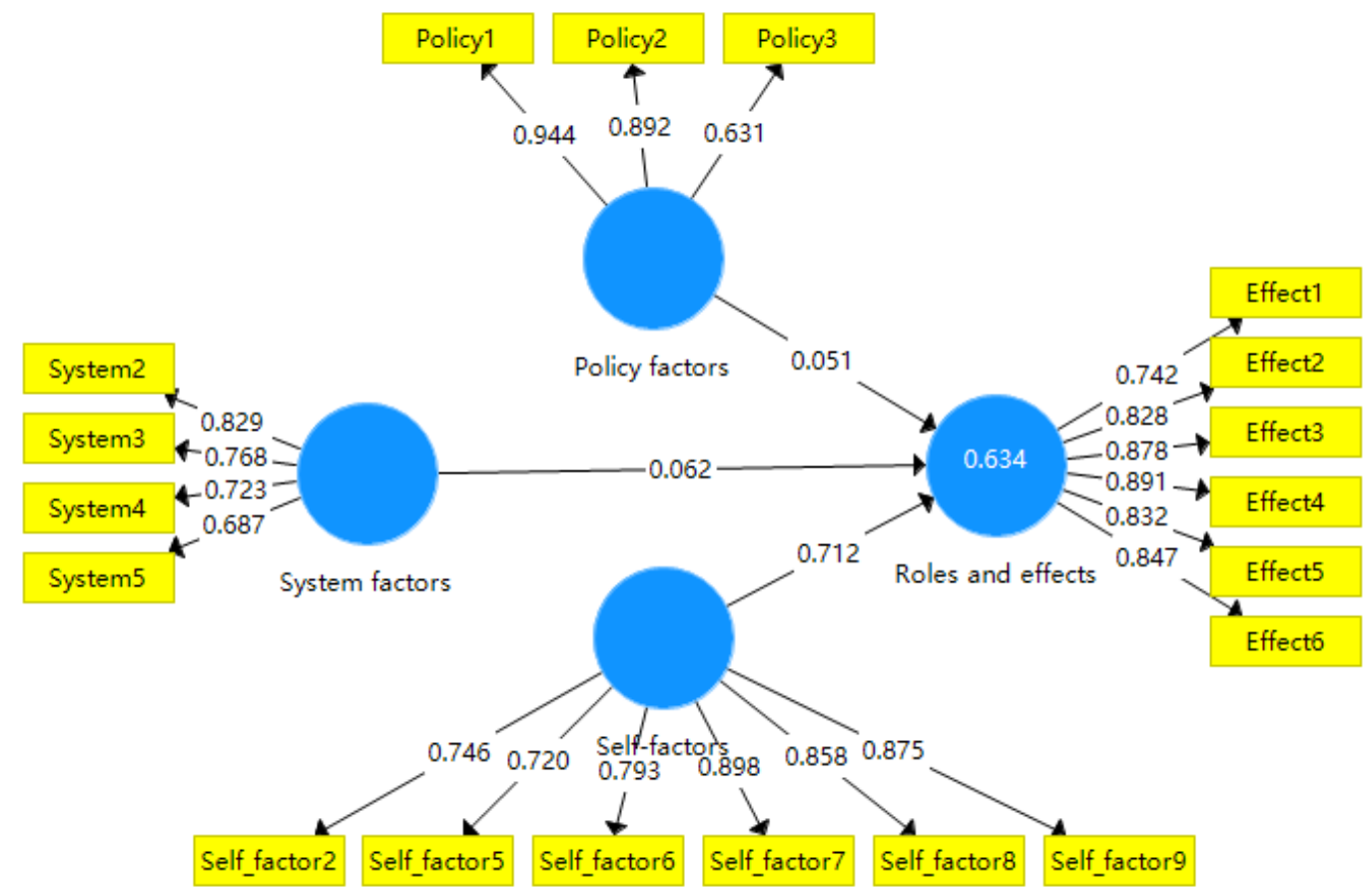

Fig. 3 Structural equation model for factors affecting the rural revitalization by scientific special commissioners

\section{Conclusions}

The results of empirical analysis show that policy factors, system factors and self-factors have a positive impact on the promoting rural revitalization by the scientific special commissioners, and self-factors have the greatest effect on rural revitalization, followed by system factors and finally policy factors. The specific observation indicators of the roles and effects of rural revitalization include the effect of the work of scientific special commissioners on the growth of agricultural products output of service objects, reduction of production costs, improvement of sales volume, increase of revenue, provision of originality, introduction of new resources, and so on.

In terms of the self-factors of scientific special commissioners, the three observation indicators, namely, enthusiasm of work affected by income, whether the appointment level is directly proportional to the work enthusiasm, and the continuous learning of new technologies and the timely updating of knowledge reserve, have low correlation with the construct of self-factors, and have low effect on the service objects in the model. Getting good financial support in the work as a scientific special commissioner has a low correlation with the classified variable, namely, system factors. Similarly, the influence degree of the selection method, channel range and service mode of scientific special commissioners on the development of science and technology services has a low correlation with the classified variable of policy factors.

In terms of the most influential scientific special commissioners' self-factors, innovating with local development features to create regional agriculture and brands, being good at using "Huinongxin" and other service platforms for benefiting farmers and assisting farmers, and putting technology and experience into words for distribution and publicity with good effect, and solving major agricultural production problems in scientific and technological services have a strong correlation, especially innovating with local development features to create regional agriculture and brands which has the highest correlation, indicating that it is an effective way for scientific special commissioners in colleges and universities to adopt local advantages and characteristics to create regional brands in rural revitalization and development.

ISSN: 0010-8189

(C) CONVERTER 2020

www.converter-magazine.info 
In terms of system factors, the reduction or exemption of the original workload of the original unit is of the highest relevance when serving as a scientific special commissioner, indicating that in the process of serving the rural revitalization, the workload of the original unit and the new unit has become an important trade-off and balance, which also greatly affects the effectiveness of the rural revitalization. In terms of policy factors, the implementation of the policy of scientific special commissioners is the main consideration indicator, and the efficiency and effect of implementation are directly related to the service efficiency of scientific special commissioners to the service objects.

Through the questionnaire survey of some scientific special commissioners, the empirical analysis shows that the work of scientific special commissioners in Fuzhou has been effectively carried out under the guidance and organization of governments at all levels, and the innovation of policies and systems has achieved certain results in assisting the rural revitalization, especially in the innovation of talent system. More and more excellent scientific special commissioners have been selected to serve farmers, enterprises and relevant villages and towns in the aspect of talent innovation. At the same time, the construction of a school-village mass entrepreneurship and innovation platform has truly combined the advantages of local characteristics to develop brands with local characteristic and fully mobilize the intellectual advantages, technological advantages and creative advantages of scientific special commissioners to serve the rural revitalization.

\section{Appendix}

\subsection{Policy factors}

Policy1: Do you think that the implementation of relevant policies of scientific special commissioners is good?_-policy implementation

Policy2: Does the government regularly carry out the training of scientific special commissioners?_ regular training

Policy3: Do you think the existing number of scientific special commissioners can meet the needs of work?_- desirable number of scientific special commissioners

Policy4: Do you think different methods, channels and service modes of selecting and dispatching scientific special commissioners have a great influence on the development of scientific and technological services?—- the influence of selecting and dispatching methods on scientific and technological services.

\subsection{System factors}

System1: Have you received good financial support in the work as a scientific special commissioner?_-Financial support

System2: When you work as a scientific special commissioner, will your original unit reduce your original workload? _ reduction or exemption of the workload in the original unit

System3: Does your work as a scientific special commissioner have a perfect evaluation mechanism?_ — perfect evaluation mechanism

System4: Does your status as a scientific special commissioner give priority to the appointment of professional titles and advanced selection?___ appraising opportunities

System5: Do you think that your current scientific and technological service work is highly compatible with your own skills?_ fit between scientific and technological work and one's own skills

\subsection{Self-factors}

Self_factor1: Will the income as a scientific special commissioner affect your work enthusiasm?_enthusiasm of

ISSN: 0010-8189

(C) CONVERTER 2020 
work affected by income

Self_factor2: As a scientific special commissioner, do you know the government's policies on scientific special commissioners?_-Understanding on the policy of scientific special commissioners

Self_factor3: Is your level of employment (provincial, municipal, county) directly proportional to your enthusiasm for the job?_employment level proportional to work enthusiasm

Self_factor4: Do you think you have the ability to learn new technologies and update your knowledge reserves in time?_- the ability to update knowledge reserves

Self_factor5: Do you communicate well with the farmers in the scientific and technological service?_communication with farmers

Self_factor6: Can you regularly provide technical business training to the recipients?_—regular business training at fixed places

Self_factor7: Can you innovate with local development features to create regional agriculture and brands?_-Building a brand with local advantages

Self_factor8:Are you good at using "Huinongxin" and other service platforms for benefiting farmers and assisting farmers, and putting your technology and experience into words for distribution and publicity, with good results?__ promoting with the platform of benefiting farmers and helping farmers

Self_factor9: Have you solved major agricultural production problems in scientific and technological services?

- solving major agricultural production problems

\subsection{Roles and effects}

Effect1: What is the effect of your work as a scientific special commissioner on the output growth of the agricultural products of the service objects__effect on the output growth of the agricultural products of the service objects

Effect2: What is the effect of your work as a scientific special commissioner on reducing the production costs of the service objects_ — the effect on reducing the production costs of the service objects

Effect3: What is the effect of your work as a scientific special commissioner on increasing the sales volume of the service objects__ effect on increasing the sales volume of the service objects

Effect4: What is the effect of your work as a scientific special commissioner on increasing the revenue of the service objects__effect on increasing the revenue of the service objects

Effect5: What is the effect of your work as a scientific special commissioner on providing originality to the service objects__effect on providing originality to the service objects

Effect6: What is the effect of your work as a scientific special commissioner on helping the service objects introduce new resources__effect on helping the service objects introduce new resources

\section{Acknowledgment}

Supported by Fuzhou Science and Technology Plan Social Development Project "A Study on Adhering to and Deepening the Scientific Special Commissioner System in Fuzhou" (Project No. 2020-CZ-38); Financial Special Project of Fujian Province "Internet cross-domain data analysis and crowd portrait".

\section{References}

[1] L.P. Lin, W.X. Liu, D.C. Zheng, et al., "Study on the Quality of life of the Internet's active population in China from the perspective of big data," 2020 Asia-Pacific Conference on Image Processing, Electronics and Computers (IPEC).

[2] D. Gefen, D.W. Straub, M.C. "Boudreau Structural equation modeling and regression: Guidelines for research practice," Communications of the Association for Information Systems 4: (2000).

[3] T. He, "Structural Equation Model PLS Algorithm,” Tianjin University, Tianjin, 2006.

[4] L.P. Lin, W.X. Liu, Z.Y. Lin, "Reliability and validity evaluation of Internet population quality of life ISSN: 0010-8189 
scale based on PLS-SEM,” Chinese Journal of Health Statistics, vol. 37, Issue. 6, pp.866-869, 2020.

[5] J.F.J. HAIR, W.C. BLACK, B.J. BABIN, et al., "Mutivariate Data Analysis," Technometrics, vol. 31 , no. 3, 2006.

[6] W.W. CHIN, A. Gopal, A.G.D. SALISBURY, "Advancing the Theory of Adaptive Structuration: The Development of a Scale to Measure Faithfulness of Appropriation," Information Systems Research, vol. 8, no. 4, pp.342-367, 1997. 